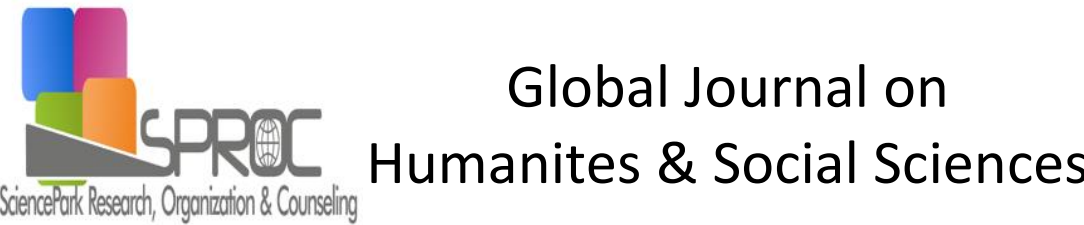

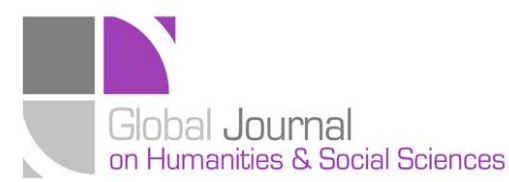

Issue 3 (2016) 667-674

Selected Paper of 4th World Conference on Design and Arts, (DAE-2015)

26-28 June 2015, St.Petersburg Christan University, St. Petersburg, Russia.

\section{Attitudes of primary school prospective teachers towards art education}

Ezel Tavşancil, Ankara University, Ankara 06590, Turkey

Seher Yalçin *, Ankara University, Ankara 06590, Turkey

\section{Suggested Citation:}

Tavşancil, E. \& Yalçin, S. (2016). Attitudes of primary school prospective teachers towards art education, Global Journal on Humanites \& Social Sciences. [Online]. 03, pp 667-674. Available from: http://sproc.org/ojs/index.php/pntsbs

Received January 01, 2015; revised March 15, 2015; accepted April 23, 2015.

Selection and peer review under responsibility of Prof. Dr. Milan Matijevic.

(C)2016 SciencePark Research, Organization \& Counseling. All rights reserved.

\begin{abstract}
This study aims to determine the prospective teachers' attitudes towards art education using Osgood affective meaning scale which takes little time to answer and is easy to administer. The study is designed in a survey model. Data was collected through all grades from the first to the forth level of primary school teaching department students who are being educated at 2014-2015 education period spring term in Faculty of Educational Sciences, Ankara University. Descriptive statistics and factor analysis were used to analyze the data. Results of analysis reveal that prospective teachers have different emotional meanings towards art education. Within this scope, suggestions concerning to develop students' attitudes towards art education were presented for academicians, education politicians and those concerned.
\end{abstract}

Keywords: Art education, attitude, primary school prospective teachers

* ADDRESS FOR CORRESPONDENCE: Seher Yalçin, Ankara University, Ankara 06590, Turkey.

E-mail address: yalcins@ankara.edu.tr / Tel.: +90-312-363-3350; fax: +90-312-363-6145. 
Tavşancil, E. \& Yalçin, S. (2016). Attitudes of primary school prospective teachers towards art education, Global Journal on Humanites \& Social Sciences. [Online]. 03, pp 667-674. Available from: http://sproc.org/ojs/index.php/pntsbs

\section{Introduction}

Art education involves educational activities performed in all fields of art (Ilhan, 2003). Art education contributes to the education of individual, society and humanity a great deal. General and educational functions of art make art education necessary (Mercin \& Alakuş, 2007). Primary education has an important role in the process of development of the mankind from simple to complex. One of the most crucial things to be done for the individual would be supplying a healthy art education, which is given with scientific sensitivity (Alakuş, 2003). When children receive art education at early ages, they get versatile while much more successful in cognitive domain lessons at the same time (Ilhan, 2003). Moreover, it is stated that art enhances creativity (Tüzün, 2013), and plays an important role in child's brain development, and provides students to express themselves better and accomplish personal development (Hurwitz \& Day, 2007). Alakuş (2003) on the other hand, deals with the necessity of art education in the primary education institutions at four levels. These are the necessities from the perspective of i) Individual, ii) Psychology, iii) Economy, iv) Sociology and politics.

As the necessity of art education is directly related to the child's progress in art, students must be provided with art education. The role of teacher in art education field is more important compared to other fields. Because in this field, the teacher must be aware of each student's talent and follow their personal development. Teachers are also obliged to make every student love art without making any distinction as talented/ untalented (Ayaydın \& Kurtuldu, 2010). This is possible with teachers' bearing awareness about the importance and the necessity of the art education, and having positive attitude towards art education. Attitude is formed when individuals organize experiences and information obtained. Attitudes are not only a behavioral tendency or just an emotion but an integration of cognition-emotion-behavior tendency (Kağıtçıbaşı, 1999; Tezbaşaran, 1996). To chance and create attitudes in individuals is a long and important process (Tavşancıl, 2010). Nonetheless, students' attitudes affect both learning and teaching processes (Pavlou \& Kambouri, 2007). On the other hand, teachers pay much more attention to Turkish and Mathematics lessons in classroom practices. This situation gives rise to thought that teachers attribute negative emotional meaning to the art education. Teachers' negative feelings may lead students towards the same way. Therefore, it is essential to determine the prospective teachers' attitudes via emotional meanings they attribute to the art education. There is no other measurement tool detected in literature to specify the prospective teachers' attitudes towards art education using Osgood affective meaning scale. This study aims to determine the prospective teachers' attitudes towards art education using Osgood affective meaning scale which takes little time to answer and is easy to administer. These are the questions that are sought to be answered for this reason: 1. What is the distribution of sensitive meanings that primary school prospective teachers assign to art education? 2 . What is the validity of structure of attitude scale towards art education? 3. Do the attitudes of the primary school prospective teachers' towards art education show a significant discrepancy according to their being involved with any kind of art? 4. Do the attitudes of the primary school prospective teachers' towards art education show a significant difference on the basis of their receiving art education or not? 5 . Do the attitudes of primary school prospective teachers' towards art education show a big difference in accordance with gender?

\section{Method}

\subsection{Model and Research Group}

This study aims to determine the prospective teachers' attitudes towards art education using Osgood affective meaning scale which takes little time to answer and is easy to administer. The study is designed in a survey model. Data was collected through all grades from the first to the forth level of primary school teaching department students who are being educated at 2014-2015 education period spring term in Faculty of Educational Sciences, Ankara University. Distribution by gender and class level of students who participated in the research is given in the table. 
Tavşancil, E. \& Yalçin, S. (2016). Attitudes of primary school prospective teachers towards art education, Global Journal on Humanites \& Social Sciences. [Online]. 03, pp 667-674. Available from: http://sproc.org/ojs/index.php/pntsbs

Table 1. Distribution of students according to their gender and class level. Class Level

\begin{tabular}{lccccc} 
gender & $\begin{array}{c}1^{\text {st }} \\
\text { grade }\end{array}$ & $\begin{array}{c}2^{\text {nd }} \\
\text { grade }\end{array}$ & $\begin{array}{c}3^{\text {rd }} \\
\text { grade }\end{array}$ & $\begin{array}{c}4^{\text {th }} \\
\text { grade }\end{array}$ & Total \\
\hline Female & 46 & 48 & 37 & 31 & 162 \\
Male & 7 & 15 & 17 & 6 & 45 \\
Total & 53 & 63 & 54 & 37 & 207 \\
\hline
\end{tabular}

As it can be seen in the Table 1, 207 students from all class levels participated in the research. It can be said that the distribution of students according to their class levels are close to each other and largely male students are few in number. This can also be a result of the smaller percentage of male students in the universe as well.

\subsection{Data Collection Instrument Data Analysis}

The data of the research is acquired via Semantic Differential Scale, which was developed by Osgood, Suci and Tannenbaum (1957: Akt. Tavşancıl, 2010). The scale, which consists of seven categories from end to end, is used to examine the semantic statistics about the attitude that individual might have. Certain bipolar adjectives are created out of many adjectives for this scale. One end of the scale is represented by the adjectives that give the most positive; the other end is represented by the adjectives that give the most negative feeling. Middle category shows that it is neutral. The positive-negative emotion points that can be derived from the scale vary between 161 and 23. It is assumed that the points of attitudes that are acquired from this scale are parametrically scaled, meaning that the distance between the scale points are equal. Tavşancıl (2010) points out that "the scale is reliable, can easily be applied, and is suitable for cross-cultural comparative measurement, and is interesting for the subjects, yet is not easy to develop, and in measuring a significant size, it requires adjectives that are related to many concepts to undergo pretesting, and needs a factor analysis to be done." In this study, bipolar adjectives that are suitable for Osgood Semantic Differential Scale are stated and taken from Tavşancıl (2010). About the suitability of scale items and bipolar adjectives that are determined to be related to art education, the clarity of the scale...etc the views of two experts from the field of art education and five measurement and evaluation experts are taken into consideration.

Data is examined for containing missing value at first, and the percentage of missing value is seen to be fewer than $5 \%$ and randomly distributed. For this reason line average is appointed to the missing values. Being one of the most important assumptions of parametric statistical tests; when normal distribution is being examined, it is seen that the attitude points of students towards art education show normal distribution in the groups who are interested in any kind of art and who are not. Moreover, it is also seen that the students' attitude points regarding art education show normal distribution in groups who received art education and who did not. Multivariate normalcy is examined with Bartlett Sphericity Tests and seen that data ensures the multivariate normal distribution assumption. In order to determine sensitive meanings of prospective teachers' regarding art education, reactions from all categories are presented with frequency and percentages. Factor structure of the scale is tested with exploratory factor analysis. Whether students' attitude towards art education is related to their interest in any kind of art, on the basis of receiving an art education of any of its kind, and the state of showing or not showing a significant difference in attitude towards art education according to their gender are tested with independent samples t test. The program SPSS-21 is used in the analysis.

\section{Findings}


In this study, in order to determine the sensible meanings of prospective teachers towards all bipolar adjectives, the frequency and the percentage of all categories are calculated and given in Table 2.

Table 2. Sensible understanding of primary school prospective teachers' towards art education

\begin{tabular}{|c|c|c|c|c|c|c|c|c|c|c|c|c|c|c|c|c|}
\hline \multirow[b]{2}{*}{$\begin{array}{r}\text { item } \\
\text { no }\end{array}$} & \multirow[b]{2}{*}{$\begin{array}{c}\text { Positive } \\
\text { adj. }\end{array}$} & \multicolumn{2}{|r|}{7} & \multicolumn{2}{|c|}{6} & \multicolumn{2}{|c|}{5} & \multicolumn{2}{|c|}{4} & \multicolumn{2}{|c|}{3} & \multicolumn{2}{|c|}{2} & \multicolumn{2}{|c|}{1} & \multirow[b]{2}{*}{$\begin{array}{c}\text { Negative } \\
\text { adj. }\end{array}$} \\
\hline & & $f$ & y & $f$ & $y$ & $f$ & $y$ & $f$ & $y$ & $f$ & $y$ & $f$ & $y$ & $f$ & $y$ & \\
\hline $\begin{array}{l}M \\
1\end{array}$ & important & 80 & $\begin{array}{c}45 . \\
2\end{array}$ & 70 & $\begin{array}{c}39 . \\
6\end{array}$ & 24 & $\begin{array}{c}13 . \\
6\end{array}$ & 3 & 1.7 & 0 & 0 & 0 & 0 & 0 & 0 & $\begin{array}{c}\text { unimporta } \\
\text { nt }\end{array}$ \\
\hline $\begin{array}{l}M \\
2\end{array}$ & good & 66 & $\begin{array}{c}37 . \\
3\end{array}$ & 84 & $\begin{array}{c}47 . \\
5\end{array}$ & 24 & $\begin{array}{c}13 . \\
6\end{array}$ & 3 & 1.7 & 0 & 0 & 0 & 0 & 0 & 0 & bad \\
\hline $\begin{array}{l}M \\
3\end{array}$ & beautiful & 81 & $\begin{array}{c}45 . \\
8\end{array}$ & 77 & $\begin{array}{c}43 . \\
5\end{array}$ & 17 & 9.6 & 2 & 1.1 & 0 & 0 & 0 & 0 & 0 & 0 & ugly \\
\hline $\begin{array}{l}M \\
4\end{array}$ & pleasant & 87 & $\begin{array}{c}49 . \\
2\end{array}$ & 65 & $\begin{array}{c}36 . \\
7\end{array}$ & 16 & 9.0 & 8 & 4.5 & 1 & .6 & 0 & 0 & 0 & 0 & $\begin{array}{l}\text { unpleasa } \\
\mathrm{nt}\end{array}$ \\
\hline $\begin{array}{l}M \\
5\end{array}$ & significant & 80 & $\begin{array}{c}45 . \\
2\end{array}$ & 69 & $\begin{array}{c}39 . \\
0\end{array}$ & 23 & $\begin{array}{c}13 . \\
0\end{array}$ & 5 & 2.8 & 0 & 0 & 0 & 0 & 0 & 0 & $\begin{array}{l}\text { insignifican } \\
t\end{array}$ \\
\hline $\begin{array}{l}M \\
6\end{array}$ & beneficial & 83 & $\begin{array}{c}46 . \\
9\end{array}$ & 66 & $\begin{array}{c}37 . \\
3\end{array}$ & 18 & $\begin{array}{c}10 . \\
2\end{array}$ & 10 & 5.6 & 0 & 0 & 0 & 0 & 0 & 0 & harmful \\
\hline $\begin{array}{l}M \\
7\end{array}$ & easy & 16 & 9.0 & 17 & 9.6 & 57 & $\begin{array}{c}32 . \\
2\end{array}$ & 48 & $\begin{array}{c}27 . \\
1\end{array}$ & 25 & $\begin{array}{c}14 . \\
1\end{array}$ & 9 & $\begin{array}{c}5 . \\
1\end{array}$ & 5 & 2.8 & hard \\
\hline $\begin{array}{l}M \\
9\end{array}$ & peaceful & 75 & $\begin{array}{c}42 . \\
4\end{array}$ & 63 & $\begin{array}{c}35 . \\
6\end{array}$ & 26 & $\begin{array}{c}14 . \\
7\end{array}$ & 12 & 6.8 & 1 & 0.6 & 0 & 0 & 0 & 0 & $\begin{array}{l}\text { unpeacef } \\
\text { ul }\end{array}$ \\
\hline $\begin{array}{l}M \\
10\end{array}$ & valuable & 84 & $\begin{array}{c}47 . \\
5\end{array}$ & 70 & $\begin{array}{c}39 . \\
6\end{array}$ & 18 & $\begin{array}{c}10 . \\
2\end{array}$ & 5 & 2.8 & 0 & 0 & 0 & 0 & 0 & 0 & worthless \\
\hline $\begin{array}{l}M \\
12\end{array}$ & interesting & 86 & $\begin{array}{c}48 . \\
6\end{array}$ & 58 & $\begin{array}{c}32 . \\
8\end{array}$ & 26 & $\begin{array}{c}14 . \\
7\end{array}$ & 6 & 3.4 & 1 & 0.6 & 0 & 0. & 0 & 0 & boring \\
\hline $\begin{array}{l}M \\
13\end{array}$ & practical & 40 & $\begin{array}{c}22 . \\
6\end{array}$ & 44 & $\begin{array}{c}24 . \\
9\end{array}$ & 50 & $\begin{array}{c}28 . \\
3\end{array}$ & 33 & $\begin{array}{c}18 . \\
6\end{array}$ & 8 & 4.5 & 2 & $\begin{array}{l}1 . \\
1\end{array}$ & 0 & 0 & $\begin{array}{l}\text { unpractic } \\
\text { al }\end{array}$ \\
\hline $\begin{array}{l}M \\
16\end{array}$ & strong & 56 & $\begin{array}{c}31 . \\
6\end{array}$ & 58 & $\begin{array}{c}32 . \\
8\end{array}$ & 35 & $\begin{array}{c}19 . \\
8\end{array}$ & 26 & $\begin{array}{c}14 . \\
7\end{array}$ & 2 & 1.1 & 0 & 0 & 0 & 0 & weak \\
\hline $\begin{array}{l}M \\
18\end{array}$ & active & 80 & $\begin{array}{c}45 . \\
2\end{array}$ & 60 & $\begin{array}{c}33 . \\
9\end{array}$ & 25 & $\begin{array}{c}14 . \\
1\end{array}$ & 12 & 6.8 & 0 & 0 & 0 & 0 & 0 & 0 & passive \\
\hline $\begin{array}{l}M \\
19\end{array}$ & creative & $\begin{array}{r}11 \\
9\end{array}$ & $\begin{array}{c}67 . \\
2\end{array}$ & 48 & $\begin{array}{c}27 . \\
1\end{array}$ & 10 & 5.6 & 0 & 0.0 & 0 & 0 & 0 & 0 & 0 & 0 & uncreative \\
\hline $\begin{array}{l}M \\
20\end{array}$ & unique & $\begin{array}{r}10 \\
9\end{array}$ & $\begin{array}{c}61 . \\
6\end{array}$ & 52 & $\begin{array}{c}29 . \\
4\end{array}$ & 13 & 7.3 & 3 & 1.7 & 0 & 0 & 0 & 0 & 0 & 0 & ordinary \\
\hline $\begin{array}{l}M \\
22\end{array}$ & critical & 58 & $\begin{array}{c}32 . \\
8\end{array}$ & 45 & $\begin{array}{c}25 . \\
4\end{array}$ & 36 & $\begin{array}{c}20 . \\
4\end{array}$ & 31 & $\begin{array}{c}17 . \\
5\end{array}$ & 6 & 3.4 & 1 & $\begin{array}{c}0 . \\
6\end{array}$ & 0 & 0 & noncritical \\
\hline $\begin{array}{l}M \\
24\end{array}$ & flexible & 60 & $\begin{array}{c}33 . \\
9\end{array}$ & 51 & $\begin{array}{c}28 . \\
8\end{array}$ & 37 & $\begin{array}{c}20 . \\
9\end{array}$ & 26 & $\begin{array}{c}14 . \\
7\end{array}$ & 3 & 1.7 & 0 & 0 & 0 & 0 & stiff \\
\hline $\begin{array}{l}M \\
25\end{array}$ & versatile & 85 & $\begin{array}{c}48 . \\
0\end{array}$ & 66 & $\begin{array}{c}37 . \\
3\end{array}$ & 16 & 9.0 & 9 & 5.1 & 1 & 0.6 & 0 & 0 & 0 & 0 & $\begin{array}{l}\text { monotoni } \\
\mathrm{c}\end{array}$ \\
\hline $\begin{array}{l}M \\
26\end{array}$ & aesthetic & $\begin{array}{l}10 \\
1\end{array}$ & $\begin{array}{c}57 . \\
1\end{array}$ & 63 & $\begin{array}{c}35 . \\
6\end{array}$ & 10 & 5.6 & 2 & 1.1 & 0 & 0 & 1 & $\begin{array}{l}0 . \\
6\end{array}$ & 0 & 0 & $\begin{array}{l}\text { unaesthe } \\
\text { tic }\end{array}$ \\
\hline $\begin{array}{l}M \\
30\end{array}$ & $\begin{array}{l}\text { contempor } \\
\text { ary }\end{array}$ & 88 & $\begin{array}{c}49 . \\
7\end{array}$ & 56 & $\begin{array}{c}31 . \\
6\end{array}$ & 20 & $\begin{array}{c}11 . \\
3\end{array}$ & 11 & 6.2 & 2 & 1.1 & 0 & 0 & 0 & 0 & $\begin{array}{l}\text { old } \\
\text { fashioned }\end{array}$ \\
\hline $\begin{array}{l}M \\
31\end{array}$ & attractive & 85 & $\begin{array}{c}48 . \\
0\end{array}$ & 64 & $\begin{array}{c}36 . \\
2\end{array}$ & 27 & $\begin{array}{c}15 . \\
3\end{array}$ & 1 & 0.6 & 0 & 0 & 0 & 0 & 0 & 0 & repellent \\
\hline
\end{tabular}


Tavşancil, E. \& Yalçin, S. (2016). Attitudes of primary school prospective teachers towards art education, Global Journal on Humanites \& Social Sciences. [Online]. 03, pp 667-674. Available from: http://sproc.org/ojs/index.php/pntsbs

\begin{tabular}{|c|c|c|c|c|c|c|c|c|c|c|c|c|c|c|c|c|}
\hline $\begin{array}{l}M \\
33\end{array}$ & realist & 57 & $\begin{array}{c}32 . \\
2\end{array}$ & 38 & $\begin{array}{c}21 . \\
5\end{array}$ & 41 & $\begin{array}{c}23 . \\
1\end{array}$ & 28 & $\begin{array}{c}15 . \\
8\end{array}$ & 6 & 3.4 & 3 & $\begin{array}{l}1 . \\
7\end{array}$ & 4 & 2.3 & dreamer \\
\hline $\begin{array}{l}M \\
34\end{array}$ & $\begin{array}{l}\text { interrogato } \\
r\end{array}$ & 63 & $\begin{array}{c}35 . \\
6\end{array}$ & 50 & $\begin{array}{c}28 . \\
2\end{array}$ & 3 & 1.7 & 28 & $\begin{array}{c}15 . \\
8\end{array}$ & 4 & 2.3 & 1 & $\begin{array}{l}0 . \\
6\end{array}$ & 0 & 0 & $\begin{array}{l}\text { acquiesce } \\
\text { nt }\end{array}$ \\
\hline \multirow{2}{*}{\multicolumn{2}{|c|}{ Average }} & 82.2 & 46.4 & 63.3 & 35.8 & 27.2 & 15. & 14.8 & 8.4 & 2.8 & 1.6 & 0. & 0.4 & 0.4 & 0.2 & Average \\
\hline & & 4 & 6 & 8 & 2 & 3 & 4 & 7 & & 5 & 2 & 8 & 5 & 2 & 4 & \\
\hline
\end{tabular}

As it can be seen in the Table 2, most students gathered around the positive bipolar adjectives. Upon examining the figures regarding the positive adjectives in the Table 2, it is confirmed that the highest figures are gathered around creative, (f: 119, \%67.2), which defines art education within a sentimental context, unique (f: 109, \%61.6), aesthetic (f: 101, \%57.1) and afterwards, modern (f: 88 , $\% 49.7$ ), interesting (f: $86, \% 48.6$ ), versatile (f: $85, \% 48.0$ ) and attractive (f: $85, \% 48.0$ ). When the figures related to the negative adjectives are examined, it is seen that very few number of students go towards the negative adjectives. The highest figure is from hard (f: $5, \% 2.8$ ), which defines art education within a sentimental context and it is followed by the adjective dreamer (f: $4, \% 2.3$ ). When the Table 2 is examined, average frequency figure of indecision level is 14.87 . It is seen that the frequency figures are increased when moving towards positive adjectives, and decreased when moving towards negative adjectives. So this shows that students overall have a positive sentimental understanding towards art education. The results of exploratory factor analysis, which was made in order to determine the theoretical structure of binary adjectives are presented below.

Table 3. Factor load figures of scale items as a result of EFA.

\begin{tabular}{|c|c|c|c|c|c|c|c|c|}
\hline Item no & Adjective & Factor1 & Item no & Adjective & Factor2 & Item No & Adjective & $\begin{array}{c}\text { Factor } \\
3\end{array}$ \\
\hline \multicolumn{2}{|c|}{$\begin{array}{l}\text { Factor } 1: \text { What does art } \\
\text { education makes you feel } \\
\text { (Emotion) }\end{array}$} & & \multicolumn{3}{|c|}{$\begin{array}{l}\text { Factor 2: Characteristics of art } \\
\text { education (Thought) }\end{array}$} & \multicolumn{3}{|c|}{$\begin{array}{l}\text { Factor 3: Point of view in art } \\
\text { education (Behaviour) }\end{array}$} \\
\hline 3 & Beautiful & .82 & 20 & Unique & .78 & 33 & Realist & .66 \\
\hline 2 & Good & .79 & 26 & Aesthetic & .74 & 13 & Practical & .62 \\
\hline 1 & Important & .76 & 19 & Creative & .71 & 7 & Easy & .62 \\
\hline 4 & Pleasant & .75 & 30 & Modern & .65 & 34 & $\begin{array}{l}\text { Interroga } \\
\text { tor }\end{array}$ & .62 \\
\hline 10 & Valuable & .75 & & & & 22 & Critical & .54 \\
\hline 5 & Significant & .68 & & & & 24 & Flexible & .44 \\
\hline 9 & Peaceful & .65 & & & & & & \\
\hline 6 & Beneficial & .61 & & & & & & \\
\hline 12 & Interesting & .59 & & & & & & \\
\hline 31 & Attractive & .59 & & & & & & \\
\hline 16 & Strong & .54 & & & & & & \\
\hline 18 & Active & .52 & & & & & & \\
\hline $\begin{array}{l}\text { Variance } \\
\text { stated }\end{array}$ & Total & 55.32 & First factor & 28.13 & $\begin{array}{c}\text { Secon } \\
d \\
\text { factor }\end{array}$ & 15.09 & $\begin{array}{l}\text { Third } \\
\text { factor }\end{array}$ & 12.09 \\
\hline
\end{tabular}

As a result of the analysis, KMO figure's (.91) being more than 0.60 and Barlett test's being significant $\left(\chi_{(231)}^{2}=1988.391 ; p<0,01\right)$; showed that answers given to the items can be factorised (Çokluk, Şekercioğlu \& Büyüköztürk, 2010; Tabachnick ve Fidel, 2007). Factor loading values of scale 
items are given in the Table 3 as a result of EFA. According to the result of the analysis that has been carried regarding whether prospective teachers' attitude towards art education show a significant difference when they are related to any kind of art or not, it is seen that students who are interested in a kind of art have (142.86) attitude points towards art education, and show a (135.47) significant difference in attitude towards art education from those who have no tendency towards any kind or art. $\left(t_{(168)}=3.82, p<.05\right)$. As a result of the analysis that has been done whether attitudes of prospective teachers towards art education show significant difference when they are received any kind of art education or not, it is seen that attitude points of students who received any kind of art education is (142.25), showed a significant difference from the attitude points towards art education of those who have not received any kind of art education (134.37), $\left(t_{(168)}=4.08, p<.05\right)$. According to the result of the analysis conducted about the significant distinction between genders of primary school prospective teachers' on their attitude towards art education, there is no significant distinction in their attitude points regarding gender on art education $\left(t_{(175)}=.96, p>.05\right)$. 
Tavşancil, E. \& Yalçin, S. (2016). Attitudes of primary school prospective teachers towards art education, Global Journal on Humanites \& Social Sciences. [Online]. 03, pp 667-674. Available from: http://sproc.org/ojs/index.php/pntsbs

\section{Conclusion and Discussion}

As a result of the research in which primary school prospective teachers' attitudes towards art education are examined with Osgood sensitive meaning method, it is seen that most of the students gathered around the positive binary adjectives. It is determined that the highest figures are gathered around the adjectives creative, unique and aesthetic, which define art education in a sentimental context. It is observed that only a few number of prospective teacher tended towards negative adjectives. It is seen that the adjective hard, which defines art education in a sentimental context has the highest figure and followed by the adjective dreamer. Upon looking at the distribution of the reactions that primary school prospective teachers give to adjectives regarding art education, it can be seen that frequency figures increase as moving towards positive adjectives and decrease when moving towards adjectives which have negative meanings. Therefore this shows that the sentimental meanings that most of the prospective teachers' attribute towards art education are rather positive. The result of the factor analysis determined that factor loading figures of the adjectives that are gathered under three factors are rather high and reliable. While a more positive attitude towards art education is determined from prospective teachers, who are related to or studied a branch of art, while prospective teachers' attitudes towards art education do not show a difference in terms of their gender. The fact that prospective teachers who have studied a branch of art have a more positive attitude shows that prospective teachers must be given an art education course. In a research that is conducted to determine the attitude of the teachers in their using art in teaching, teachers express themselves as considering art education important, yet they seldom use art in their class. The reason for that is stated as their having low self-esteem regarding art education applications (Oreck, 2004). This situation, as it came out with the research can also be explained with prospective teachers who have an interest towards any kind of art, have higher attitude points. In a research that is conducted to determine primary school students' attitudes towards art education, it is seen that students' perception of art is limited to the role of talent (Pavlou \& Kambouri, 2007). Generally evaluating the studies, it can be stated that individuals who have an interest or talent towards any branch of art also have a positive attitude towards art education. With the help of the developed scale, after the attitudes of the prospective teachers' towards art education are detected, studies may be conducted to make the prospective teachers' negative attitudes positive. Prospective teachers' having a positive attitude towards art education will make their students realize the importance of art education. As there is no research done using the sentimental meaning scale in the related literature, it increases the importance of the results of this research and makes it more eye-catching.

\section{References}

Alakuş, A. O. (2003). In view of individuals primary age the necessity problematic of art education. Electronic Journal of Social Sciences, 4, 1-9.

Ayaydın, A. \& Kurtuldu, M. K. (2010). Development of an attitude scale toward art education. Firat University Journal of Social Science, 20 (2), 201-209.

Çokluk, Ö., Şekercioğlu, G. \& Büyüköztürk, ş. (2012). Sosyal bilimler için çok değişkenli SPSS ve LISREL uygulamaları. Ankara: PegemA Yayıncilık.

Hurwitz, A. \& Day, M. (1995). Children and their art (Methods for the elementary school). Florida: Harcourt Brace College Publishers.

IIlhan, A. Ç. (2003). Training programs for classroom teachers and art education. Ankara University, Journal of Faculty of Educational Sciences, 36(1-2), 13-23.

Kağıtçıbaşı̆, Ç. (1999). Yeni insan ve insanlar (10. Baskı). Sosyal Psikoloji Dizisi: 1, İstanbul: Evrim Basın Yayın Dağıtım.

Mercin, L. \& Alakuş, A. O. (2007). The necessity of art education for individual and social. Dicle University Journal of Ziya Gökalp Faculty of Education, 9, 14-20.

Oreck, B. (2004). The artistic and professional development of teachers: A study of teachers' attitudes toward and use of the arts in teaching. Journal of Teacher Education, 55(1), 55-69.

Özdamar, K. (1999). Paket programlar ile istatistiksel veri analizi. Eskişehir: Kaan Kitabevi.

Pavlou, V. \& Kambouri, M. (2007). Pupils' attitudes towards art teaching in primary school: An evaluation tool. Studies in Educational Evaluation, 33. pp. 282-301. 
Tavşancil, E. \& Yalçin, S. (2016). Attitudes of primary school prospective teachers towards art education, Global Journal on Humanites \& Social Sciences. [Online]. 03, pp 667-674. Available from: http://sproc.org/ojs/index.php/pntsbs

Tabachnick, B. G., \& Fidell, L. S. (2007). Using multivariate statistics (5th Ed.). Boston: Allyn and Bacon. Tavşancıl, E. (2010). Tutumların ölçülmesi ve SPSS ile veri analizi. (3. Baskı). Ankara: Nobel Yayınları. Tezbaşaran, A. (1996). Likert tipi ölçek geliştirme kılavuzu. Ankara: Türk Psikoloji Derneği Yayınları.

Tüzün, M. (2013). Fine art education and creativity in Turkey. European Journal of Research on Education, Special Issue: Art in Education, 12-15. 